\title{
New name for the soft coral Alcyonium rubrum Stokvis \& van Ofwegen, 2006 (Alcyonacea, Alcyoniidae): Alcyonium burmedju nom. $n$.
}

\author{
Íris Sampaio ${ }^{1,2}$, Frank R. Stokvis ${ }^{3}$, Leen P. van Ofwegen ${ }^{3}$ \\ I IMAR - Instituto do Mar \& MARE - Marine and Environmental Sciences Centre, Universidade dos Açores, \\ Departamento de Oceanografia e Pescas, Rua Prof. Dr. Frederico Machado 9901-862, Horta, Açores, Portugal \\ 2 Senckenberg am Meer, Abteilung Meeresforschung, Südstrand 40, 26382, Wilhelmshaven, Germany 3 Na- \\ turalis Biodiversity Center, P.O. Box 9517, 2300 RA Leiden, The Netherlands \\ Corresponding author: Íris Sampaio (irisfs@gmail.com) \\ Academic editor: B. W. Hoeksema | Received 4August 2016 | Accepted 7 September 2016 | Published 27 September 2016 \\ http://zoobank.org/7DD8AB82-4D16-4DB7-9236-97E66979A11A \\ Citation: Sampaio Í, Stokvis FR, van Ofwegen LP (2016) New name for the soft coral Alcyonium rubrum Stokvis \& \\ van Ofwegen, 2006 (Alcyonacea, Alcyoniidae): Alcyonium burmedju nom. n. ZooKeys 619: 163-165. doi: 10.3897/ \\ zookeys.619.10086
}

\section{Keywords}

Octocorallia, zoological nomenclature, homonymy, East Atlantic

Alcyonium rubrum Stokvis \& van Ofwegen, 2006, an encrusting soft coral (Figure 1), was described from the Northeast Atlantic Ocean based on specimens collected during the Dutch CANCAP VII Expedition to the Cape Verde Archipelago (Stokvis and van Ofwegen 2006). This species was later reported from the Azores (Braga-Henriques et al. 2013).

A review on the taxonomic literature of octocorals by the first author revealed the existence of a species described from Scandinavia under the same name, Alcyonium rubrum Müller, 1776, which was also reported from Ireland (Hassal 1841). In such a case of primary homonomy, the International Code of Zoological Nomenclature Article 60 , states that the junior homonym is invalid and needs to be replaced by a new name. We propose to replace Alcyonium rubrum Stokvis \& van Ofwegen, 2006 by Alcyonium burmedju nom. n.

Copyright Íris Sampaio et al. This is an open access article distributed under the terms of the Creative Commons Attribution License (CC BY 4.0), which permits unrestricted use, distribution, and reproduction in any medium, provided the original author and source are credited. 

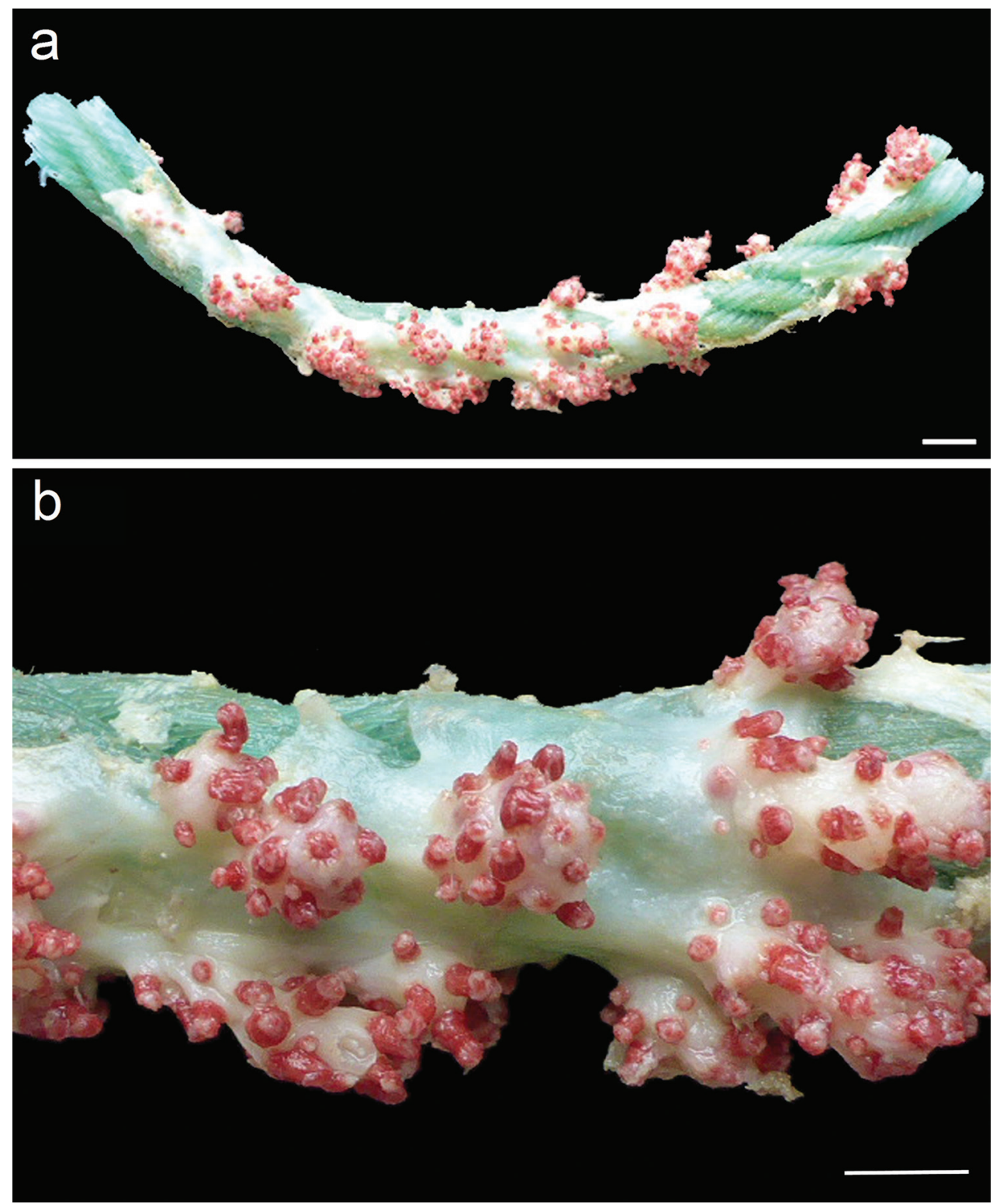

Figure I. Holotype (RMNH Coel. 33879) of Alcyonium rubrum Stokvis \& van Ofwegen, 2006, renamed Alcyonium burmedju nom. n. a Fishing rope serving as substrate for the encrusting soft coral (scale bar: $10 \mathrm{~mm}$ ) b Detail of the colony. Scale bar: $5 \mathrm{~mm}$.

Etymology. The epithet "burmedju" means red in the criolo language spoken on Santiago Island in the Cape Verde Archipelago. The type locality is south of Raso islet, also localized in this island group (Stokvis and van Ofwegen 2006). Red is the predominant polyp colour of this species (Figure 1). 


\section{Acknowledgements}

The first author is funded by an FCT Doctoral grant SFRH/BD/101113/2014 and received a Marine and Environmental Sciences Centre (MARE) travel grant to visit the Invertebrate Collection of Naturalis Biodiversity Center, Leiden. Koos van Egmond offered assistance in accessing this collection. This work has received funding from the European Union's Horizon 2020 research and innovation programme, under grant agreement No 678760 (ATLAS). This output reflects only the author's view and the European Union cannot be held responsible for any use that may be made of the information contained therein. We would like to thank Maria Rakka for helping with the image processing and two anonymous referees for taking time to add valuable comments that improved the manuscript.

\section{References}

Braga-Henriques A, Porteiro FM, Ribeiro PA, de Matos V, Sampaio Í, Ocańa O, Santos RS (2013) Diversity, distribution and spatial structure of the cold-water coral fauna of the Azores (NE Atlantic). Biogeosciences 10: 4009-4036. doi: 10.5194/bg-10-4009-2013

Hassall AH (1841) XXXIII - Supplement to a Catalogue of Irish Zoophytes. Journal of Natural History 7(44): 276-287. doi: 10.1080/03745484109442700

ICZN (1999) International Code of Zoological Nomenclature ( $4^{\text {th }}$ edn). International Trust for Zoological Nomenclature. London, 306 pp.

Müller OF (1776) Zoologiae Danicae prodromus, seu animalium Daniae et Norvegiae indigenarum characteres, nomina, et synonyma imprimis popularium. Hallageriis, Havniae, 282 pp. doi: 10.5962/bhl.title.13268

Stokvis FR, Van Ofwegen LP (2006) New and redescribed encrusting species of Alcyonium from the Atlantic Ocean (Octocorallia: Alcyonacea: Alcyoniidae). Zoologische Mededelingen 80(4): 165-183. 